\title{
THE BUSINESS PURCHASE AGREEMENT AND LIFE INSURANCE
}

\author{
SAMUEL M. FAHR*
}

For many years the death of one of the owners of a closely held business, whether sole proprietorship, partnership, or closed corporation, has posed for the survivors (and their lawyers) some of the most intricate and indeed apparently insoluble problems of law and business. The havoc that usually follows such a death is all too well known to those who have had to deal with one.

I do not propose to deal in detail with the evils which live after businessmen, but a short summary of the more serious effects of the death of a sole proprietor, partner, or shareholder in a closed corporation will help to point up the problem. Almost invariably there is an exceedingly severe shrinkage in the realizable value of partnership assets; it may run as high as 75 per cent, and has been said to average close to 50 per cent. ${ }^{1}$ It is just as true that the sale of shares of a closed corporation is almost certain to produce inequity, if not downright hardship; there is all too often great difficulty in realizing a price which will even pass muster with the probate court, and the sale of a majority interest lays surviving shareholders open to changes in control which may entirely alter their status vis-a-vis the corporation. The forced sale of the assets of the sole proprietorship likewise can hardly be hoped to produce even their book value. In addition, in the case of any business organization in which relatively few persons exercise direction and control, the good will section of the balance sheet may vanish entirely. On the other hand, when the taxing authorities value these same assets, they usually arrive at a figure far in excess of what can actually be secured for them. ${ }^{2}$ But this is far from all. Income to the surviving widow ceases, and woe betide the executor who decides in his infinite compassion to run the business out of sympathy for her; ${ }^{3}$ the surviving partner too is under a fiduciary duty ${ }^{4}$ to wind up the business as quickly as possible, ${ }^{\overline{5}}$ unless there is an enforceable agreement to the contrary. ${ }^{6}$ In the case of all three forms of business association the delays caused by the passage through probate of the business assets or of the shares which represent an interest in the business add to the woes of all the parties concerned. In the case of the partnership and sole proprietorship all business continuity is likely to be lost.

In brief, then, the death of a central figure in any one of the three forms of

- A.B. 1940, LL.B. 1943 (1947), Harvard University. Assistant Professor of Law, University of Iowa.

2 Edwin H. White, Bustness Insurance r4r-r 42 (1949).

${ }^{2}$ Miller, When the Court Values Yout Stock, Insurance Research and Review Service (1947).

${ }^{3}$ Kick v. McCauley, Schwerzler v. McCauley, I 8 N. J. Eq. 252, I78 Atl. 637 (I935).

Keyes v. Hurlbert, 43 Cal. App. 2d 497, III P. 2d 447 (194I).

Uniforar Partnershri Act $\$ 33$.

- Id. 5537,43 . 
business association which we are considering generally leads to delay, lack of liquidity, inexperienced new owners, uncertainty, and a host of other ills too numerous to mention here, although not necessarily unimportant for all of that. ${ }^{7}$

Naturally, estate planners, long before that impressive title was coined for them, were not backward in trying to smooth out transition upon death. Partnership agreements were drafted providing that the survivor should continue the business for a stated period. The sort of legal entanglements such a scheme entails, particularly with regard to creditors of the partnership, is vividly illustrated by the notorious case of Stewart $v$. Robinson ${ }^{8}$ and its companion pieces. ${ }^{9}$ In the case of closed corporations, fearful of the consequences which befell when informal plans for the continuation of a business were used, ${ }^{10}$ the estate planners drafted more formal plans, but all too often-despite care and legal counsel-with disastrous results. ${ }^{11}$ Many other schemes were tried, ${ }^{12}$ but were found to be more ingenious than workable.

For the average situation what is wanted is a scheme which leaves the decedent's estate in the possession of cash in an amount which will be the fair equivalent of the decedent's interest in the business, and which leaves the business to the survivors as free of unsettled claims and of the dislocating shocks caused by death as is humanly possible. $^{13}$ If in addition to these minimum requirements, administration of estate and inheritance taxes can be made more satisfactory, the credit of the business can remain unimpaired, and other effects of death can be minimized or eliminated, that is all to the good. A suitable purchase agreement would accomplish most of this.

The problem has been to raise the cash to finance the purchase. To fund it by annual deposits for the purpose was never easy, and modern taxes make it harder. Furthermore, in most cases the older member of the business will die first, and by an unhappy paradox he is the one most likely to be able to raise the money for the purchase. Finally, if a death occurs before there has been a chance to build up a fund, such a purchase agreement will probably fail.

Another manner of financing the agreement is to use long term notes in payment for a deceased businessman's share. But such notes are hardly a substitute for.full payment in cash, and may be hard to meet in the period following a death while the business is getting going under a change of management.

\footnotetext{
TWure, op. cit. supra note $\mathrm{I}$, at $\mathrm{II}-\mathrm{I} 5, \mathrm{I} 30-\mathrm{I} 52,276-287$; and see Haddad, Disposition of Business Interests, I ILL. L. FORUM IXS (1949). .

${ }^{8}$ II5 N. Y. 328,22 N. E. 160 (I889).

${ }^{\circ}$ Delameter v. Hepworth, 115 N. Y. 664,22 N. E. 163 (1889); Butcher v. Hepworth, 115 N. Y. 328,22 N. E. 163 (1889).

${ }^{10}$ Gaines Bros. Co. v. Gaines, 176 Okla. 576, 56 P. $2 \mathrm{~d} 869$ (x936).

${ }^{11}$ In re Block's Will, I 86 Misc. 945,60 N. Y. S. $2 d 639$ (Surr. 1946).

${ }^{12}$ For good discussions of these schemes, see WHITE, op. cit. stipra note $\mathrm{I}$, at $26-77,144 \cdot 170,288$. 314. As to parmerships only, Forster, Legal, Tax, and Practical Problems Under Partnership Purchase and Sale Agreements Coupled With Life Insurance, I9 So. CaL.IF. L. REv. I (x945), is very good, pointing out limitations in many commonly employed devices.

1s There may be circumstances in which they will want to wind up and begin again; or it may be desired to take a decedent's son into the business, etc.
} 
But since the problem to be solved at this point is the raising of a large sum of ready cash at death, the twentieth century mind at once thinks of life insurance. And in fact the modern solution to the dilemma is to couple the purchase of reciprocal life insurance policies on the lives of the business associates with a binding agreement among them that at the death of any one of them his share shall pass to the survivors: what is known among the cognoscenti as a "Business Purchase Buy and Sell Agreement," the subject of this article.

The device is not new. A British author, writing in 1905 , spoke of it as a "system ... in vogue for many years." ${ }^{14}$ In this country, after the turn of the century there has been a gathering momentum in its use, until today there is no doubt that the buy and sell agreement constitutes one of the heaviest pieces of ordnance in the arsenal of the life insurance producer. ${ }^{15}$ Although the law reviews have so far pretty largely ignored the phenomenon, ${ }^{16}$ those lawyers and others who write for the "trade magazines" have not, and in recent years there has been a perfect spate of articles devoted to the discussion of life insurance and the buy and sell agreement. Every life underwriter is keenly aware of the opportunities for production in the field; but (Tell it not in Gath!) much conversation with both life insurance men and with lawyers has convinced me (and what is far worse, the underwriters) that the lawyers are very far indeed from that state of knowledge which is not a dangerous thing. However, it is also safe to say that since the need for understanding is there, and since there is obviously money in knowing how to meet the problems raised by the device we are considering, the lawyers will sooner or later adapt to it as they have to taxation and administrative law. It is the purpose of this article to explore the use of life insurance and the business purchase buy and sell agreement to see what are its potentialities, what are the forms it takes, and what are the dangers in the use of it to be avoided or at least skirted as well as may be. It is patent that all the issues (consider, for example, taxation) cannot be treated exhaustively; rather I intend to survey the field and point out key problems and possible solutions to them.

Let us begin by looking at the salient features of an "ideal" business purchase buy and sell agreement. ${ }^{17}$ After a clause or two of an explanatory nature, there is likely

14 T. P. Wansbrough, The Case for PartnershtP Assurance (London, I905). Many of the most pressing problems of today are dealt with by this author.

${ }^{15}$ Life insurance companies do not find it profitable to keep track of the purposes for which insurance is purchased, consequently in estimating the importance of business purposes one has to proceed "by guess and by God." However, many conversations with underwriters and insurance company executives lead to complete belief that a great deal of insurance is sold today with buy and sell agreements as the motivation. A most interesting survey in the central Middle West was recently made under the auspices of the University of Illinois, and it certainly substantiates what has been said here. RoBERT I. MEFR" AND Hugh G. Wales, Business Life Insurance and Its Economic Applications (1950).-

${ }^{10}$ For instance, an excellent article in the Yale Law Journal doesn't mention insurance used to fund such agreements. See Fuller, Partnership Agreements for Continuation of an Enterprise after the Death of a Partner, 50 Yale L. J. 202 (I940).

${ }^{17}$ Readers who are interested can procure sample forms from almost any life insurance company. These forms are exceedingly helpful in drafting. 
to be a formal agreement on the part of each to sell at death to the survivors his share of the organization, on conditions to be detailed later; the survivors likewise agree to buy such an interest on stated terms. There will follow a paragraph devoted to the method by which a decedent's share will be valued at death so as to fix the price of purchase. After a recital of the insurance which has been taken out to finance the contract, beneficiaries of the policies are named, and the agreement as to how premium payments shall be made is set forth. There will be directions to the executors or administrators as to their duties vis-a-vis the estate of the deceased and the survivors in the business. The duties of the trustee, if one is to be beneficiary of the policy, will be outlined. Directions to surviving members of the organization as to payment of debts, etc., may be set forth. Provision will be made for amendment of the agreement, and for procedures to be followed in the event a member leaves the business before death. And numerous other terms and conditions to meet the thousand natural shocks that business is heir to will be included. I haven't space to consider all of them at this time.

Then if the job has been well done, the death of any member of the company will see something like this happen. The beneficiary of the policy on the life of the decedent will almost immediately have cash for the estate; and this liquidity will also represent a fair value to all hands. The company, on the other hand, will continue to function almost without a jerk, which will satisfy the survivors and company creditors alike. The taxing authorities will get their fair share and no more. For all interested parties there will be a minimum of expense, uncertainty, inconvenience, and sacrifice. Everybody will be as happy as it is possible to be under the circumstances, and will bless the day the agreement was entered into. ${ }^{18}$

But, alas, it isn't so easy in practice. The drafting of such agreements is often exceedingly difficult, and involves a knowledge of insurance (both as to law and company practice), taxation, and draftsmanship, as well as an ability to foresee future pitfalls and changes and to provide for them. It is really a branch of estate planning, ${ }^{19}$ and in fact so little understood by many lawyers as to lead insurance men to be distrustful of the average attorney let loose in this field, ${ }^{20}$ and to lead an acknowledged master of the art of estate planning to describe the situation as "disappointing."21 One might almost say that the practitioner in this area must combine the best traits of Solomon and a legal version of Leonardo da Vinci. Let us see why.

The first hurdle is to persuade the business associates to enter into such an agreement. But in practice all the evidence is to the effect that this is easy; business-

\footnotetext{
${ }^{18}$ At various points throughout his book, White points out the ideal solution and its many advantages.

${ }^{10}$ In Mayo A. Shattuck, An Estate Planner's Handeook 58.65 (1948), the author devotes eight pages to a consideration of buy-sell agreements.

${ }_{20}$ This conclusion is reluctantly reached following many conversations with life underwriters and attorneys.

${ }^{21}$ Shattuck, op. cit. stipra note 19, at 64 .
} 
men are aware of the problem and so anxious to solve it they sometimes almost sell themselves. Allied with the need for selling the idea is the practical difficulty, happily for lawyers resting chiefly on the life underwriter (who in almost every case has nursed the situation along till legal advice is needed), of selling enough insurance to finance the purchase when death occurs. Obviously if the entire agreed price can be paid by way of insurance proceeds, the contract will be most easily performed. Failure to buy enough insurance is a common hindrance to many plans. At all events, although there doesn't seem to be anything strictly unethical about the lawyer playing the role of part-time salesman here, ${ }^{22}$ this branch of the art of persuasion should be left to the life underwriter. If the parties will not or cannot buy enough insurance to finance the purchase, it is customary to use notes for the balance. This will be discussed in another connection below.

A far more important problem, which is more "practical" than "legal," is that of valuing the assets on the death of a member of the association. It will be recalled that one incentive leading to the business purchase scheme was to assure that a fair price was paid for a decedent's share of the business. It therefore follows that great care should be used to see that the clause dealing with valuation of a decedent's interest to establish the price of transfer is fair and realistic. And change being in the nature of things, there certainly ought to be provision made for periodic reappraisals of the value of the assets. Furthermore, the method chosen will influence federal estate taxation, as I shall discuss later. Failure to provide for a suitable means of valuation is catastrophic. Yet it sometimes happens.

There are many different methods of valuing assets. ${ }^{23}$ Since this sort of agreement is to be tailormade, it is well to remember that what will serve very well for one type of business may be unrealistic for another; for example, contrast a "service" partnership ${ }^{24}$ with a "trading" partnership. ${ }^{25}$

It is hornbook accounting that when the book value of assets and the "fair" value or "market" value coincide you have the exception that proves the rule. ${ }^{26}$ Therefore I think it is best categorically to rule out book value as the method of final valuation.

A method of valuation very commonly used is to have the members of the business association who are parties to the buy and sell contract periodically meet to

12 It is not even inferentially treated in the American Bar Association Canons of Professional Ethics.

${ }^{28}$ For a very complete discussion of valuation methods, see Hugh C. Bickford, Successfur TuI Practice (I950). Although primarily devoted to tax matters, this book contains exhaustive accounts of strengths and weaknesses of various systems used in the valuation of all sorts of property. Id, at 42-9I.

'D Davis, Liquidation of Partnership Equities in Private Medical Clinics, I J. AMrerran Soc'y of Chartered LIFE UNDeRwriters (1946), hereinafter referred to as C. L. U. J. The distinction between "trading" and "professional" or "service" partnerships may be a tyranny of labels, but it certainly exists in the language of many courts; obviously the distinction is between partnerships selling primarily goods, and those selling primarily services.

${ }^{20}$ Davis, Valuation of Business Interests, 2 C. L. U. J. (1946).

${ }^{20}$ And even book value is far from as certain a quantum as some accountants would have one believe. If it must be used, for a short discussion of how it can be used fairly, see Grorge J. LnIRIN, Death? Taxes, and Your Business 22-23 (I948). 
thresh out a valuation for the assets. At first blush this seems a most practical way of achieving the desired result: all sides have their respective says (which, after all is the foundation of the "adversary" system of law), ${ }^{27}$ and it also sees to it that there is the needed periodic reappraisal. Experience shows that the catch in it is that the parties tend to forget to make the valuation at the prescribed intervals; thus it is perfectly possible that a I950 death may be faced with a I945 valuation. Wise draftsmen consequently provide for a buttressing method of final appraisal in case at death the most recent periodic valuation by the associates has been skipped. And the least that can be done is for the underwriter, or perhaps the lawyer, to maintain a "tickler" file to remind him to remind his clients of this matter.

Another common device for measuring value is to provide for independent appraisal upon death. The estate appoints one appraiser, the survivor associates appoint another, and these two appoint a third. Or again, the agreement appoints supposedly independent appraisers, either by name or by office (e.g., "Whoever shall be president of the First National Bank," etc.). It is desirable to include a formula to guide the appraisers; examples of formulas which are sometimes employed will be discussed below. ${ }^{28}$ Certainly at all events there ought to be explicit instructions for the valuation of uncollected items, contingent liabilities, and other items of an uncertain character, including the elusive item of good will.

Formulas to be applied at death are very popular, and have the added virtue that they gladden the heart of the publicans ${ }^{29}$ and those who deal with them..$^{30}$ Whatever formula or combination of formulas is used, it may be applied by the company's own auditor or accountant, or by an outside accountant, subject, of course, to review by the estate and the survivors. The formulas available to choose from are myriad, but they fall into a few general categories. A common one is to set value at book value ${ }^{31}$ plus the good will, the latter to be determined by an agreed formula. It cannot be overemphasized that it should be made clear that good will, and the formula to be used to evaluate it, are included. ${ }^{32}$ The formulas which seek to attribute value to good will generally fix a specific percentage of average profits for a period of no less than five years and proceed to capitalize it at an agreed rate (often I5 or 20 per cent). It is important that this sort of formula be re-examined from time to time, as fair rates for capitalization may vary in any business, and the per-

${ }^{27}$ But $c f$. White, op. cit. stipra note I, at 94 . He fears a deadlock in the typical sole proprietorship case (wherein one or more employees will usually be party to the agreement).

28 Forster, supre note 12, at 25.

${ }^{29} 26$ CODE FED. Regs. \$81.ro(d) (Cum. Supp.) (valuation of property-interest in business).

${ }^{30}$ Bachrach, How to Value Property for Estate Tax Purposes, $86 \mathrm{~J}$. Accountancy 397 (1948).

s1 To be determined, of course, from company books and records. It should be emphasized that even here there must be instructions to the appraiser as to proper allowances for bad debts and the many similar variables. And should such unrealized factors as asset appreciation be taken into account?

${ }^{32}$ As horrible examples of what happens when this is not done, particularly with respect to postmortem income of a partnership, see Keyes v. Hurlbert, 43 Cal. App. 2d 497, 111 P. 2d 447 (1941), and Hull v. Cartledge, 18 App. Div. 54, 45 N. Y. Supp. 450 (2d Dep't 1897). The issue was, were profits carned after death to be held included in the valuation of the assets? See also Nelson, Some Reflections on the Value of Good Will, 2 C. L. U. J. 269 (1948). 
centage attributable to good will likewise changes with the amount of profits and their sources.

Or the parties may agree to capitalize earnings out and out, on any basis which seems fair to them. Such a valuation will, of course, include good will. This is a method familiar to accountants, and it may be that the parties will be satisfied with a capitalized value established by their own accountant. This method also has been fully described in many readily available authorities, which gives it added usefulness. $^{33}$ There are a host of authorities which deal with application of capitalization to earnings, ${ }^{34}$ but for our purposes the method actually used is not so important as that it be made clear what it is, and that there be provision for changes where circumstances make them advisable.

It is too clear for argument that a permanently fixed value, to prevail come hell or a Republican President, will be as unsatisfactory a solution to the valuation problem as could be devised. And it is hardly likely in these days that the parties will agree to accept the valuation of the federal or local taxing authorities. Besides, the defect in such plan is that there is considerable uncertainty and there may be a delay of up to at least 15 months in arriving at that figure, ${ }^{35}$ whereas one object of the entire purchase plan was to achieve certainty and expedite matters for all concerned. Where the agreement is in option-to-buy form (not recommended for tax reasons), the best bona fide offer received may be suitable. ${ }^{36}$

To sum up, then, the provisions as to valuation are vital to the success of the plan for purchase. They must be fair and they must be clear. In addition they should be re-examined periodically. To carry them out it is necessary that the company keep adequate books, so that the appraisers, whoever they may be and whatever the method they must follow, may have access to accurate and complete information. This last requirement, as a matter of fact, has proved in some cases to be a very useful by-product of the agreement, particularly in smaller businesses.

Far more important and difficult of solution than the valuation problem is the matter of who shall be beneficiaries of the policies. ${ }^{37}$ On this choice hang many tax consequences, issues involving the rights of creditors, and other vital matters. One reason for the difficulty is that in the choice of a beneficiary two important principles are often at war: the interest in the smoothest possible functioning of the plan, and the interest of each member of the business in question in taking advantage of the settlement options common to life insurance. It has been stated that

\footnotetext{
${ }^{33}$ For example, see 2 Randolph E. Paul, Federal Estate and Gift Taxation 1290-1293 (1942), 784 (1946 Supp.).

st Among them, Sprecher, The Valuation of Stock in a Closely-Held Corporation for Federal Gift and Estate Tax Parposes, 31 Kr. L. J. 325 (1943); Edwakd N. Polisher, Estate Planning and Estate Tax SAving 307 (2d ed. 1948).

sE INT. REv. CODE $\$ 822(a)(1)$.

${ }^{\text {so }}$ Currie, Buy and Sell Agreements With Respect to Corporate and Partnership Interests, [1950] W1s. L. REV. I2, 19.

${ }^{37}$ Deane C. Davis, Life Insurance and Business Purchase Agreements 3 (1948). This short publication of the National Life Insurance Company of Vermont is very clear and useful.
} 
"business liquidation is the primary goal," and that the use of the options is a "by-product."38 No doubt that is perfectly true, but not every client is as reasonable as "thee and me." There are two reasons why many persons are tempted to think that it is desirable to subordinate complete liquidity to the familial interest: a desire to avoid probate, and the fear, justified in some cases, that it may be impossible to take advantage of the settlement options unless they are elected inter vivos by the named insured himself. How nice it would be, thinks the prospect, to by-pass the courts and have the policy I am about to take out double as a liquidator and an addition to my personal insurance program. ${ }^{39}$ These arguments are not at all unreasonable, and must be treated seriously. It will be helpful in this part of the discussion to treat each of the three forms of business organization separately, since the same conclusions as to choice of beneficiaries do not apply equally to all of them.

In the case of the sole proprietorship, the buy and sell agreement is likely to be between the owner and one or more of his employees, since generally they will be the only persons capable of taking over his business and making a success of it. ${ }^{40}$ Assume that horrible examples have been cited, ${ }^{41}$ and a purchase agreement decided on-who shall be beneficiary of the insurance? One immediate choice would be the trusty employee who stands certain to take over. Not only is this simple, but it has the added merit of putting each side-the estate of the decedent and the purchasing employee-in a position where it has one important trump card-the insurance proceeds versus the business assets in the hands of the executor. When each side has what the other needs you are likely to see prompt performance of the contract.

This same approach suggests that the decedent's estate is a poor choice as beneficiary of the insurance, since to let the executor get control of both the title to the decedent's business assets and the life insurance puts the executor in a position in which it would tax an angel to avoid using the leverage thus created. The courts will enforce the agreement, ${ }^{42}$ but there is plenty of scope for harassing and delaying

${ }^{38} \mathrm{~J}$. M. Huebner, Business Liquidation Insurance and Optional Settlements, in The BeNericiary iN LIFE INSURANCE I82 (I948).

${ }^{30}$ This idea may be particularly potent where the insured is comparatively young. Often he can't afford to pay these premiums and support a very large personal life insurance program, and he is likely to regard the buy-sell scheme as a case of reciprocal insurance (though not, let us hope, in the same sense as it was held reciprocal in Lehman v. Comm'r, 109 F. $2 \mathrm{~d} 99$ (2d Cir.), cert. denied, 3ro U. S. $637(2940)$ ) to be coordinated with his personal insurance plans. He will also have justifiable concern about his future insurability. "And see Hrrst, Business Life Insurance and Other Topics 12 (1949). Haddad, supra note 7, at $116-117$, suggests that raising salaries to meet the cost of premiums on the insurance may result in a net tax saving; but isn't this "indirect payment" of premiums? INr. REv. Code $\S 8 \mathrm{II}(\mathrm{g})(\mathrm{2})(\mathrm{A})$.

"0 Perhaps the lawyer, in the case of the sole proprietorship, ought to urge formation of a partnership or incorporation. The drawing of a buy-sell agreement gives a good chance for thorough review of the entire business set-up.

${ }^{41}$ As to this, see Conant v. Blount, I4I Fla. 27, 92 So. 48I (1939); and see Jacob, Trusts for Continuing a Decedent's Business, I 8 Iowa L. Rev. 43, 44-45 (r932).

${ }^{42}$ I can find no cases so holding, but from partnership cases to be cited below it is perfectly clear that they will do so. 
tactics. And despite benevolent statutes, there is always a danger that the creditors of the deceased proprietor may levy on the proceeds of the policy. ${ }^{43}$ And there is a risk of added estate taxation. ${ }^{44}$ Finally, there is grave danger that this will result in exclusion of insurance proceeds from the buyer's cost basis on his sale of company assets acquired by way of the purchase and sale agreement. ${ }^{45}$

But I haven't yet dealt with the temptation to integrate the insurance proceeds with the decedent's private insurance program, by making the policy payable to the proprietor's widow (or other family beneficiary) so as to take advantage of the settlement options. Certainly it is tempting to do so, both in a small estate, where testamentary trusts are not feasible, and in a larger estate, where there may be federal income tax advantages to doing so if the widow's tax bracket is high enough. ${ }^{46}$ And insurance salesmen are loath to desert one of their finest selling points. Nevertheless, it is well to resist naming the widow as beneficiary. For one thing, here again there may be unforeseen tax consequences for the buyer in that the insurance proceeds may be excluded from his cost basis of the assets purchased under the agreement. $^{4 i}$ Furthermore, although no cases have been found treating of the problem, it would not be unreasonable for a court to treat the transaction as in fraud of creditors, for whereas the decedent was just before death possessed of considerable assets, now by virtue of the agreement the assets must be conveyed to the surviving purchaser, and yet the proceeds of the sale by-pass the estate and go directly to the widow. This is a risk it is better to avoid. ${ }^{48}$ Besides, this beneficiary designation loses that nice balance of power spoken of above, for here the wife gets the insurance proceeds, and the executor has the duty of conveying the assets to the purchaser. All these objections lead one to the conclusion that there are definite risks in treating the business purchase proceeds as part of the personal program of the proprietor. Certainly a careful adviser ought to lay these probable disadvantages before the parties so they may look before they leap.

One final beneficiary designation is to use a corporate trustee as beneficiary, making him a party to the agreement. This has several advantages. The trustee can hold the policies, thus obviating assignment of them or other misuses. He can

\footnotetext{
"s See generally, Spencer, Rights of Creditors in Life Insurance, in The Benefrciary in Life Insurance esp. 39-107 (1940).

"For 2 hint of this, see Estate of John T. Mitchell, 37 B. T. A. I (1938).

${ }^{25}$ Legallet v. Comm'r, 4 I B. T. A. 294 (r940).

48 For example, if she is in a 50 per cent tax bracket, there may be tax economy under 26 CoDe Fed. Regs. \$29.22(B) (r)-r (Cum. Supp.) (exemptions, exclusions from gross income) as amended by 26 Code Fed. Regs. \$29.22(B)(I)-r (Cum. Supp. 1946), and Comm'r v. Pierce, 146 F. $2 d 388$ (2d Cir. 1944). But since these will usually be, even in the soie proprietorship agreement, insurance on the lives both of the proprietor and a key employee (who is the proprietor's opposite party in the agreement), this may boomerang; the Commissioner may argue that this is as reciprocal as the Lehman case, supra note 39; else why should the survivor select the decedent's widow as beneficiary?

17 See note 45 supra.

${ }^{48}$ See Murphy v. Murphy, 217 Mass. 233, 104 N. E. 466 (1914), in which the court indicated it would be alert to detect a fraud on creditors. Also the decedent's next of kin might claim the proceeds, alleging that they represent the business assets and hence should be treated as part of the estate. Forster, supra note 12 , at 6.
} 
supervise payment of the premiums. When death occurs, he collects the proceeds of the policies he holds, and sees that they reach the proper hands only after arrangements have been made to transfer the business assets in accordance with the agreement, including all the necessary transfer documents, such as deeds, assignments of accounts receivable, etc. There is thus provided a sort of referee who, being impartial, will see to it that there is as little friction as possible. Against the use of a trustee several arguments are made. In the case of small businesses-and sole proprietorships tend to be small-the cost may discourage the parties. This objection may be insuperable. But in businesses of any size whatever, it will pay the planner to investigate, for there is a very good chance that trustee fees for this sort of trust will be considerably smaller than those for trusts imposing continuous active duties. While the parties are alive this trustee's job is very easy, and consequently there is no reason to charge the fees required where active management is involved. ${ }^{40}$ A further objection is that by using a trustee all chance of taking advantage of the settlement options is lost. But that "ain't necessarily so." A survey of insurance companies made in 1945 showed that the majority of twenty-one leading companies were willing to allow a corporate trustee to select options, and there is reason to believe that the tendency of company practice is all in that direction. ${ }^{50}$ There are thus likely to be real advantages in the use of a trustee, and few disadvantages, unless cost is out of proportion to the size of the business. The future should see wider use of corporate trustees as beneficiaries of such policies as the virtues of such a designation become more widely known.

In the consideration of beneficiary designations for a partnership agreement, many of the arguments discussed when dealing with the sole proprietorship apply. Let us consider first the situation in which the surviving partner is beneficiary of the policy of the decedent. There is very little doubt that a majority of states will hold the buy and sell contract valid and specifically enforceable..$^{51}$ But there are practical

${ }^{8}$ Out of nineteen middle western trust companies with whom the question of fees charged for administering trusts in business purchase buy and sell agreements was discussed by the author, nine stated positively that they charged materially less net fees for the administering of such trusts, five said they believed lower charges would be fair, and only three of the rest stated categorically that they would not lowè their fees for such trusts.

${ }^{50}$ Forster, supra note $\mathrm{I} 2$, at 23 n. 80 . There is a good deal of variation from company to compahy with respect to granting option selection privileges to trustees. Customarily they require that the selection be made within a definite period, but that should not be onerous. Certainly they are getting miore friendly to persons anxious to get the privilege extended to trustees.

61 That the agreement is valid in general, see Note, 73 A. L. R. 983 (193I); and 40 Asr. Jur. Partnerships $\$ 347$ (1942). That it is a binding contract, see McKinnon v. McKinnon, 56 Fed. 409 (8th Cir. I893); First National Bank of Rome v. Howell, I95 Ga. 72, 23 S. E. 2d 415 (1942); Ireland v. Lester, 298 Mich. 154, 298 N. W. 488 (r94r); Kavanaugh v. Johnson, 290 Mass. 587 , 195 N. E. 797 (1935). That it is nontestamentary, see Ireland v. Lester, stupra; Coe v. Winchester, 43 Ariz. 500, 33 P. 2d 286 (1934) (community property state, held, insured had right to sell his interest in the partnership. He must have been a selling challenge; in a letter he referred to "Those Kansas City life grafters"). But $c f$. Ferrara v. Russo, "40 R. I. 533, roi Atl. 86, L. R. A. (N. s.) 1918B, 905 (1917), nullified by General Laws of R. I. c: 428, 1 Io (1938). Kavanaugh v. Johnson, supra, also holds that the relationship between the amount' of the insurance and the value of decedent's share in the business is immaterial. 
disadvantages to this arrangement. ${ }^{52}$ Once again an unfavorable balance of power is created: the survivor has control of both the firm assets and the proceeds of the policy. Quite apart from any imputations of malice or dishonesty, this exposes the decedent's estate to the hazards run by the survivor, such as death, personal financial troubles, and the like. Nor is it at all likely that the settlement options can be made eventually available to the widow under this arrangement. Firm creditors will be sorely tempted to reach the proceeds, and the least they can do is to make trouble and delay. Thus, though this beneficiary designation has been called "logical," 3 it is not entirely satisfactory.

The laudable desire to by-pass probate and to take advantage of the settlement options has led many to make the decedent's widow the beneficiary. Cases upholding such arrangements have been careful to stress that there were no creditors of the estate pressing claims to the proceeds or the firm assets; ${ }^{54}$ by implication it would seem that there is danger that if such creditors should enter the picture the entire scheme would be in jeopardy. ${ }^{55}$ This would be particularly true if the purchase price was strikingly inadequate. There would be similar danger if the survivor was the beneficiary of the policy; a fortiori the danger would exist where both were true. There would be a serious risk that creditors or the next of kin of the deceased partner could, and possibly should, upset the agreement. There are no cases on this point. Implications of the Legallet case $^{56}$ raise tax issues better avoided. There may be unnecessary estate tax problems. ${ }^{57}$

To make the partnership itself the beneficiary seems inexcusable. There is no chance of employing settlement options on behalf of the widow under these circumstances. The proceeds become partnership assets, subject to all sorts of claims and delays. There is a distinct possibility that the proceeds, swelling the firm assets, will be taken into account in determining the decedent's federal estate tax liability, ${ }^{58}$ thus allowing his estate the benefit of taxation without representation. And the death of a partner ordinarily dissolves the partnership.

There remains the possibility of employing a corporate trustee as beneficiary of the insurance policies. This seems by all odds the best solution for most situations. Where the trustee holds the policies, collects the insurance, and in general oversees as a neutral the working out of the agreement at death, all parties are likely to get fair play. The use of a trustee creates a balance of power, is not unduly expensive, as aforesaid (particularly if smoothness of operation of the plan is valuable), and the trustee can in most instances select settlement options as needed. By holding the ownership rights in the policies, the trustee obviates the danger that there will

v2 Off, Beneficiary Problems of Non-Trustee Partnership Insurance Agreements, I4 TEMP. L. Q. 490, 493 (I940).

${ }^{63}$ WhITE, op. cit supra note 1 , at 215 .

* E.g., Murphy v. Murphy, 217 Mass. 233, 104 N. E. 446 (1914).

${ }^{65}$ Davis, op. cit. supra note 37 , at 8, 9. 4 B. T. A. 294 (1940).

${ }^{67}$ Dobrzensky v. Comm'r, 34 B. T. A. 305 ( $x 936$ ).

${ }^{8 B}$ INT. REv. Code $\$ 81 \mathrm{r}(\mathrm{a})$. See note 62 infra. 
be abuse of such rights. When death occurs, the agreement can give the trustee extensive powers of supervision of the working out of the plan and contract, including valuation of the assets, and transfer of them to the survivor simultaneously with delivery of the proceeds of the policy. It will be advisable to provide arrangements in the buy and. sell agreement itself for transfer of partnership real property to the trustee, so that when the agreement is consummated the trustee can convey the realty to the survivor as both legal and equitable titleholder. (This is a matter on which the forms furnished by many insurance companies are deficient.) All things considered, a competent corporate trustee is the best possible beneficiary.

In some respects at least, the selection of a beneficiary in the case of a closely held corporation is not so difficult as in the other two forms of business association. For example, the shares of stock of themselves represent the decedent's interest; there are not the same complex problems of property transfer that may occur in the case of a partnership. But there are difficulties all the same.

One solution to the beneficiary problem is to name the surviving shareholders. This has the merit of balancing their bargaining power-the possession of the insurance proceeds-against that of the estate-the possession of the shares. There is not the same chance for harassment by creditors in the case of a corporation that there is in a partnership, since the corporate creditors normally aren't given rights against the shareholders personally. The proceeds will probably be included in the cost basis of the survivors, thus eliminating the problems of the Legallet case. There is very little chance that the transfer will be declared in fraud of the survivor's creditors, although the possibility exists where there is a serious disproportion between the "value" of the interest in the shares acquired and the price. On the other hand, the chance to use settlement options is lost. This is the solution employed in many business purchase agreements.

The decedent's estate is often suggested as beneficiary. It is not very satisfactory, for some of the same reasons that rendered the estate an undesirable beneficiary in the case of the sole proprietorship. There is the failure to create a balance of power; the estate temporarily controls both the shares of the deceased and the life insurance proceeds. And this arrangement exposes the insurance proceeds to attacks by the decedent's creditors; they may be beaten off, but they will be tempted. There will be no chance to employ beneficial settlement options. There may be controversy over the amount of decedent's estate taxes, in that the Treasury may attempt to tax both the value of the shares and of the proceeds in the estate. ${ }^{50}$ Although the attempt will usually fail, the chance of it should be avoided.

To make the widow of the decedent the beneficiary suffers from the same defects in a corporation situation as it did in the case of the partnership, although because

\footnotetext{
${ }^{89}$ Estate of John T. Mitchell v. Comm'r, 37 B. T. A. I (1938). This attempt on the part of the Commissioner failed. See Deputy Commissioner Bliss's Memo of November 24, 1947, reported in CCH I948 FED. Estate AND Gift TAX Rep. q6012.
} 
of the nature of the property interest, i.e., shares of stock, the defects may be somewhat less severe. ${ }^{60}$

Very frequently the corporation itself is named as beneficiary. This is sometimes called a "stock retirement" plan. ${ }^{61}$ It is more workable in the case of a corporation than it was in the partnership case to name the business association beneficiary; the corporation is immortal, comparatively speaking, and the shareholders own certificates of stock and not firm assets. But the insurance proceeds in this case enhance the decedent's interest in the company and thus swell his estate tax unnecessarily. ${ }^{62}$ And there are further limitations on this beneficiary designation which have led at least one writer to dub the agreement useful but unenforceable. ${ }^{63}$ It is particularly useful in the case where there are more than a few shareholders, for in that case the buy and sell contract may become highly complex and cumbersome. For example, under a buy-sell agreement there is a chance that proportionate interests in the corporation may be upset by a death, owing to inability on the part of some shareholders to buy enough of the dead man's stock to maintain their relative position. ${ }^{64}$ This is not true in the "stock retirement" case. It may, however, be unenforceable because the corporation may not have the power to buy its own stock. ${ }^{65}$ The so-called "American Rule" restricts such purchases to funds supplied out of surplus, ${ }^{66}$ but "surplus" is as roguish as Equity ever thought of being. ${ }^{67}$ What kind of surplus? Do paid-in surplus, or a revaluation surplus qualify? Will the same rules which apply to the declaration of dividends (weak enough to be sure) also apply to retirement of corporate stock? Is the case of paid-in surplus used to retire a discount on other stock a good analogy? These and other questions as to the nature of the surplus available have not been answered by the courts. ${ }^{68}$ Even if "surplus" exists, may a corporation retire its own stock when arrearages exist as to preferred stock? ${ }^{69}$ Furthermore, in some states the purchase of its own stock by a corporation is entirely

${ }^{\circ 0}$ Davis, op. cit. supra note 37 , at 8.

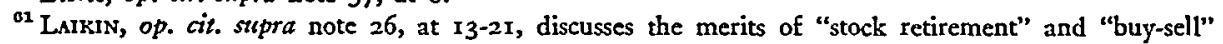
plans and compares them.

${ }^{\circ}$ Newell v. Comm'r, 66 F. 2d 102 (7th Cir. 1933); Estate of W. A. Blair, 4 B. T. A. 959 (1926).

${ }^{63}$ Williams, $A$ Useful, Unenforceable Contract, 3 C. L. U. J. 325 (x949). The title, however, is misleading. What Mr. Williams means is that the contract is unenforceable if. . . And he confines himself to New York cases.

"This is especially likely to be true where life insurance has been unavailable for some members of the corporation and so some must purchase from personal funds. The plan may function more equitably if the corporation is obligated to make the purchase in such a case.

or See generally, 6A Wilina M. Fletcher, Corporations \$2845 (1950); Henry W. Ballantine, Corporations $\$ 256 \mathrm{a}$ et seq. (rev. ed. 1946). See also Dodd, Purchase and Redemption by a Corporation of lts Own Shares, 89 U. of PA. L. Rev. 697 (I94I), and Levy, Purchase by a Corporation of Its Own Stock, I5 Minn. L. REv. I (1930).

${ }^{60}$ Ballantine, op. cit. supra note 65 , at 604 .

${ }^{\circ 7}$ Sec, e.g., Randall v. Bailey, 23 N.Y.S. 2 d I73 (1940), aff'd, 288 N. Y. 280,43 N. E. $2 d 43$ (1942), noted in 54 Harv. L. Rev. 505 (1940). And see Note, 56 Harv. L. Riev. 645 (1943).

${ }^{\circ 8}$ There certainly is a trend in the courts to limit the uses to which the various kinds of "surplus" may be put. But this form of accounting sophistication is moving into the courts with all the animation of a glacier.

${ }^{00}$ Note, I $_{4}$ U. OF ChI. L. REv. 66 (1946). 
forbidden by statute, ${ }^{70}$ or at least hedged about with many statutory restrictions. ${ }^{71}$ Besides all this, can it be predicted, even in a "liberal" state, that when the next shareholder dies there will be a surplus available even in the soundest company? Some decisions have gone further and held stock purchase plans are unenforceable as lacking in consideration, since they are exposed to the possibility that at that time they may be impossible to perform for lack of surplus; ${ }^{\mathbf{7 2}}$ but these cases have been limited by later ones. ${ }^{73}$ Will building up of reserves under the policies fall afoul of Section I02 of the Internal Revenue Code, as being unreasonable accumulations of surplus? ${ }^{74}$ Finally, will the survivors find that they are paying a heavier capital gains tax on eventual sale of their shares because the insurance proceeds are not included in the cost basis of their stock ? ${ }^{\text {T5 }}$ The fact that these questions can be asked but not satisfactorily answered, indicates that perhaps a wise planner will think carefully before naming the corporation beneficiary. In fact, however, this is a very common designation.

There remains for consideration the naming of a corporate trustee as beneficiary. As aforesaid, this is not expensive, affords impartial supervision of the working out of the plan, and generally allows selection of settlement options. There is no Section I02 problem. If desired it can be provided that the trustee shall have authority to pay sufficient funds over to the executor or administrator in case the decedent's personal estate is insufficient to meet his debts. This seems the best solution in most cases, and in fact is being increasingly adopted.

Closely allied to the question of who shall be beneficiary of the policy is the question of who shall apply for and control the policy till death occurs. This involves payment of premiums, and control of all the incidents of ownership. A rule of thumb often employed is that the beneficiary should pay the premiums and that control should be in the person who pays the premiums. The problems are both practical and legal; among the legal problems those of taxation predominate.

For a number of reasons the insured should not apply for the policy. In order to separate control of the policy from control of the stock whose later purchase it is to finance, the insured if he has applied for the policy will have to assign the policy to the trustee, other partner, corporation, or whoever is finally to control it. This involves a possibility of taxation at death to the latter as a "transferee for value."1"

${ }^{70}$ Note, 30 Mare. L. Rev. 138 (1946).

${ }^{71}$ E.g., KY. Rev. STat. \$271.120 (1942).

72 Topken, Loring and Schwartz v. Schwartz, 249 N. Y. 206, 163 N. E. 735 (1928).

${ }^{73}$ Greater New York Carpet House v. Herschmann, 258 App. Div. 649, 17 N. Y. S. $2 d{ }_{483}(3 \mathrm{~d}$ Dep't 1940); Steinbugler v. Atwater and Co., 289 N. Y. 816, 47 N. E. $2 d 432$ (1943).

is The fact that the corporation could accumulate the surplus, by way of the reserve values on the policies, arguably means the surplus was unnecessary in the business. Much will hinge on who really paid the premiums. Cf. General Smelting Co., 4 T. C. 3 r3 (1944) (involving "credit" and "key-man" insurance).

${ }^{75}$ Int. Rev. Code $\$ 115(c)$. Raum, Stock Pttrchase Agreements Among Stocliholders of Close Corporations in New York University Eighth ANnUal Institute on Federal Taxation 702-706 (1950). As to the problem of the shareholder who withdraws, see John Bridge, 7 T. C. M. 249 (1948).

${ }^{70}$ INT. Rev. CODE $\$ 22(b)(2)$. Where the insurance is written first, followed immediately by the buy-sell agreement and the assignment of the policy, the "transfer for value" is purely formal. 
The case is likely to arise where the salesman has sold first and helped consummate the purchase agreement afterward-a not unnatural phenomenon.

Nor should the insured have any sort of control over the policy. From a practical standpoint this exposes him to a temptation to borrow on the policy or even perhaps to cash it in. What has he got to lose?

As to the problem of taxes, control in the insured raises the specter of having the insurance included in the gross estate of the insured together with his interest in the business. ${ }^{77}$ This double taxation is at present unnecessary. Furthermore, if that was done some of the reasoning in the Legallet case might be applied so as to lower survivor's cost basis by the amount of the insurance proceeds, although without all the incidents of ownership present in that case it must be admitted that this is not a necessary result.

Certainly the best and simplest procedure is to have the beneficiary apply for the insurance initially and control it thereafter. As has briefly been shown, and as will be developed more fully later, this minimizes taxation and leaves control in the party least likely to abuse it. It is far less likely that one will try to realize on such a policy when one knows that the acquisition of another's interest depends on having the full face value of the policy. Nevertheless, it is sometimes a part of the buy and sell agreement to include a provision that the beneficiary who controls the policy must give notice to all other members of the group, of any intention to exercise any of the incidents of ownership, or to provide for a penalty in case any member, at the death of another member of the group, cannot meet the terms of sale. ${ }^{78}$

As to payment of the premiums, it will be remembered the rule of thumb was that the person who controlled the policy should pay the premiums. He should be expected to pay for what he expects to use to buy out a decedent's interest, on general principles. After all it is a purchase, not a gift, transaction. Furthermore, caeteris paribus, it is inequitable for a sixty year old man to pay premiums on himself when the other party is only thirty-five or forty; mortality expectations and unequal premium requirements should serve to eliminate such an arrangement.

If the insured himself pays the premiums, the plain language of Section $8 \mathrm{II}(\mathrm{g})$ makes a very strong case for including in the gross estate not only the business interest but also the proceeds of the life insurance. ${ }^{79}$ Although there are cases which point away from this form of double taxation, ${ }^{80}$ they all date from before the Revenue Act of 1942, which included in the gross estate, among other things, insurance on which the decedent paid premiums or possessed incidents of ownership. Thus there is grave doubt whether those cases are law today, and in any case they are only

\footnotetext{
${ }^{77}$ INr. Rev. CODE $\$ 8 \mathrm{Ir}(\mathrm{g})(2)$ B. As to this sort of "double taxation" see Hilgedag, Life Insurance Planning for Estate and Gift Taxes in NEw York University Fifth ANNUAL INstITUTE on Federal TAXATION 25, 4I (1947).

${ }^{78}$ Lawther, Some Problems in Business Purchase Agreements in Business Purchase Agreements 7 (1946).

${ }^{70} 26$ Code Fed. Regs. $\$ 8$ r.27 (Cum. Supp.) (insurance receivable by other beneficiaries).

${ }^{\text {so }}$ Estate of John T. Mitchell v. Comm'r, 37 B. T. A. I (1938); Dobrzensky v. Comm'r, 34 B. T. A. 305 (1936); Boston Safe Deposit and Trust Co. v. Comm'r, 30 B. T. A. 679 (1934).
} 
decisions of the Board of Tax Appeals. No conscientious adviser should permit the risk of such needless double taxation. ${ }^{81}$ Nor need he, for there seems to be no reason for having the insured pay the premiums directly.

By the same token, payment of the premiums by the business organization is highly risky. In the case of a partnership particularly, if it pays premiums and charges each partner with the premiums on his policy, pretty clearly he has paid the premiums "indirectly." 82 But if no such allocation is made and the total of all premium payments is charged as a partnership expense, then any given partner can be construed to have made only a pro rata payment of premiums on his own life. Yet in the light of the plain language of the Code, why should that matter? Pretty plainly he has paid for the insurance on his own life in either case, and regardless of "fairness" the insurance proceeds ought to be included in his own gross estate. As has been stated, this is an "unhappy consequence" 83 but one which it will take an exceedingly able argument to avoid. ${ }^{84}$ Therefore, avoid company payment of premiums, at least in the case of the partnership and sole proprietorship. Even in the case of the closed corporation, where control centers in a few, the same rationale may very well be applied. ${ }^{85}$

There is even a chance that where the individual members own the policies on the others and pay no premiums on policies covering their own lives, there may be controversy over indirect payment. Apparently relying on Lehman $v$. Commissioner, ${ }^{80}$ the Bureau at first stated informally that where partners paid premiums on each others' lives they would be held to have paid premiums on their lives indirectly. But the Lehman case was obviously a tax dodge and a phony, and the Bureau finally retreated at least part way ${ }^{87}$ so that today it is a fairly safe bet that where there is a legitimate business purchase agreement of the sort we are talking about there will be no allegation of indirect payments so long as the members of the group pay premiums on each others' lives from personal funds. Nor should there be any such allegation, in the light of the purpose of Section $8 \operatorname{Ir}(g)(2)(A) .{ }^{88}$ However, to date, the matter has not been settled by any reported cases.

Where a trustee is utilized as owner of the policy, it would seem that it is equally

81 I PaUi, op. cit. supra note 33, \$\$10.34-10.39; 2 JacoB Rabkin and Mark H. Johnson, Federal Income, Gift and Estate Taxation 3713 (1944). See Matthews, Estate Tax Consequences of Agteements for the Sale of a Partnership Interest Effective at the Partner's Death, 26 TEx. L. REv. 729, 742 et seq. (1948).

82 INT. REv. CODE $\$ 81 I(g)(2)(A)$.

${ }^{83}$ Bowe, Life Insturance, The Forbidden Frtit, 2 VAND. L. Rev. 213, 225 (1949).

"What of H. R. REP. No. 2333, 77th Cong., 2d Sess. I62 (1942); SEN. ReP. No. 1631, 77th Cong., 2d Sess. 235 (1942): "This provision is intended to prevent avoidance of the estate tax and should be construed in accordance with this objective."

${ }^{86}$ Foosaner, When Are Life Instrance Premiums Paid Indirectly?, I C. L. U. J. 369 (1947). That this may be considered indirece payment of premiums only in the case of great corporate control by decedent, see I PAUL, op. cit. supra note 33, \$10.36 (1946 Supp.), and see 26 Code Fed. Regs. \$8r.27 (Cum. Supp.) (insurance receivable by other beneficiaries): "A decedent similarly pays the premiums or other considerations if payment is made by a corporation which is his alter ego. . ..."

${ }^{80}$ See note 39 supra.

${ }^{88}$ See note 82 supra. Of cousse any intra-family arrangement will invite suspicion. 
important to avoid any suspicion of indirect payment. It is certain that the tax authorities and the courts will look through the formal to the substantial, and consequently, however the payments are made, the test employed is bound to be to consider the ultimate source of premiums. There is nothing to be gained by trying to insulate the parties behind a trustee.

Sometimes premiums are pooled, with each paying an equal share, or sometimes paying a share based on proportionate interests. Clearly, if interests are equal, and premiums are pooled so that payments are equal, the older member of the group is paying more than he should. Or if interests are unequal a similar disproportion is obtained. Only in the freak situation where interests and ages are equal can a fair result be predicted for all parties. Some of the inequitable consequences of pooling can be rectified by giving a decedent's estate a pro rata share of the cash values of all policies as such values stood at the date of death, ${ }^{89}$ but that seems to introduce new complications in a situation already complex enough.

To sum up, then, ideally the best arrangement would be to name a corporate trustee beneficiary, have it apply for and own the policies, and avoid all possible indirect payment of premiums.

When a death occurs, the estate of the decedent will own rights in policies written on the lives of survivors. These interests ought to be taxed as part of the decedent's gross estate. ${ }^{90}$ In any event, it is customary in buy and sell agreements to provide that survivors shall have an option to buy from the estate within a stated period after a death the policies on their respective lives, paying therefor usually the cash surrender value of such policies and crediting the decedent's estate with its share of such values created by decedent's premium payments. This is often a very beneficial arrangement for the survivors, for frequently they have become uninsurable, and certainly they would probably be unable to get new policies then at such favorable rates." There is of course a "transfer for value," that this is no deterrent and that the survivors are only too happy to pick up the policies.

So far as the tax aspects of business purchase agreements are concerned, it is obvious that no article as short as this one could begin to do them all justice. The law reviews, and journals devoted to tax matters and insurance are full of discussion of many facets of possible tax problems. Some tax matters have been treated throughout this article as they arose, often, it must be admitted, in summary fashion. But I believe some attention should be given to two major issues of a tax nature: the question of the binding effect of the valuation provisions of the purchase on valuation for federal estate tax purposes, and the problems of the Legallet case. ${ }^{93}$

It is very common to hear life underwriters state, as one selling feature of a buy

${ }^{80}$ WhITE, op. cit. stupra note I, at 213-214, 34I-342.

${ }^{\circ 0}$ INT. Rev. Code $\S 8 \mathrm{rr}(\mathrm{a})$. This problem is well treated in Note, 48 Cot. L. Rev. 450, 454-455 (1948).

91 White, op. cit. supra note I, at 355-356; LAWTHER, op. cit. sttpra note 78 , at 14 .

${ }^{95}$ INT. REV. CODE $\$ 22($ b) (2).

${ }^{23} 4$ x B. T. A. 294 (1940). 
and sell agreement, that the valuation method used for adjusting matters among the members of the business association is conclusive for federal estate tax purposes. They are encouraged in this belief by much of the promotional literature furnished them. One can hardly blame them for lack of entire comprehension of the witty diversities of federal estate taxation. And generally speaking they are very likely to be right. But there are gins and snares aplenty which can beset those who believe blindly in the conclusiveness of such valuations. Some warnings should be set in their path.

To begin with, that dangerous (!) family relation may interfere to cause the courts to say that it was all a sham. There is here so much danger of a less than arm's length dealing that tax authorities are naturally suspicious, and the agreed price has been rejected where the contract price is completely unrelated to the "fair market value" ${ }^{94}$ of the interest. ${ }^{95}$ However, in that case there was no evidence whatever of an arm's length bargain. But where a father and son were completely at odds, if not downright enemies, the agreed price was upheld, ${ }^{90}$ and this despite the fact that the option price was less than ro per cent of the Commissioner's "market" valuation of the stock.

Another criterion which has been given weight is this: where the decedent was not bound by the sale agreement during his lifetime and there were no provisions against the sale of the interest inter vivos, the valuation section of the buy-sell agreement will not be given effect.97 The rationale of this test seems to be that restrictions not binding till death cannot affect the value of the property till death, being, rather, "testamentary in character." 98 There was in the Matthews case no relationship by blood or marriage between the parties. Furthermore, from the agreement itself it is strongly inferable that the parties intended that inter vivos sales outside the group should be forbidden. This case ignores two factors: first, that the interest is to be valued at death and thus the option agreement certainly then became a burden on the price which could have been secured for the stock; and second, that both Section $8 \mathrm{II}$ (c) and (d) provide that the gross estate shall not include property transferred at or after death where such transfer amounts to a "bona fide sale for an adequate consideration in money or money's worth." The case has not escaped criticism. ${ }^{.0}$

\footnotetext{
24 26 Code Fed. Regs. \$8r.ro (Cum. Supp.) (valuation of property) as amended by 26 Code Fed. REcS. \$81.10 (Cum. Supp. I944).

${ }^{95}$ Claire Giannini Hoffman, 2 T. C. 1160 (1943), aff'd on other issues, 148 F. $2 \mathrm{~d} 285$ (9th Cir), cert. denied, 326 U. S. 730 (1945). And see Armstrong's Estate v. Comm'r, 146 F. $2 \mathrm{~d} 457$ (7th Cir. 1944).

${ }^{90}$ Commissioner v. Bensel, too F. 2 d 639 (3d Cir. 1938), affirming 36 B. T. A. 246 (1937).

87 Estate of James H. Matthews, 3 T. C. 525 (1944). This case and others like it are thoroughly treated by Matthews, stupra note 81 , at $735-738$.

${ }^{88}$ Estate of James H. Matthews, stipra note 97 , at 529.

${ }^{98}$ Ness, Federal Estate Tax Consequences of Agreements and Options to Purchase Stock on Death, 49 Cot. L. Rev. 796 (1949); Matthews, stupra note 81, at 736; Note, Valuation of Stock Stubject to Restrictive Agreenzent for Federal Estate and Gift Taxation, 60 Harv. L. Rev. 123 (1946); Polisher, Valuation of Business Interests for Federal Estate Tax and Pennsyluania Transfer Inheritance Tax, 48 Dick. L. REv. 121, 123-126 (1944).
} 
It raises the further question: what is a restriction inter vivos which will be considered sufficiently binding to justify accepting the valuation provided for by the agreement? Since we are concerned with closed corporations, the position of majority interests therein becomes particularly tenuous in this connection. And it is doubtful whether a "first offer" agreement, effective inter vivos, will qualify as sufficient, ${ }^{100}$ although it must be taken into consideration in the valuation process.

The net of all these cases on estate tax valuation and buy-sell contracts appears to be that as yet there is no "rule" which can be laid down. There are no Supreme Court decisions in the field, and the more recent cases are tending toward a disregard of valuations established in restrictive agreements. ${ }^{101}$ It is difficult at present to predict what standards will eventually be adopted as we await the gradual pricking out of criteria by the courts. In the interim the best that the adviser can say to his client is that an agreement binding at death, entered into by parties who dealt at arm's length and untainted by family relationship or anything smacking of donation is certainly the safest bet to be accepted by the courts as establishing a "fair market value" for the interests concerned; certainly those are the criteria which have been used to date.

As to the effect of the Legallet case, ${ }^{102}$ the facts in that case indicate the traps which ought to be avoided. It is so horrible an example of what not to do that the late Professor Joseph Warren would undoubtedly have called it a "menagerie case." Each of two partners took out insurance on his own life, payable to his own wife, and retained all the incidents of ownership in the policies. Premiums were paid by the partnership and charged as a firm expense to the partners equally, though there was considerable disparity in their ages. There was an ordinary buy and sell agreement, which provided, among other things, that regardless of the value of a decedent's interest at death all the proceeds of the insurance were to go to his wife. One partner died, and the survivor paid the balance of the purchase price not covered by insurance proceeds by way of notes. Later the survivor sold some of the accounts receivable and merchandise of the former partnership; he was unsuccessful in trying to include in his cost basis for this sale the proceeds of the life insurance on his dead partner. It is hard to see how this result could have been avoided, under the circumstances. Note the earmarks: first, a policy taken out by a partner on his own life; second, payment to be to the partner's own wife; third, retention by the insured of all incidents of ownership in the insurance; finally, payment of the premi-

\footnotetext{
${ }^{100}$ Worcester County Trust Co. v. Commissioner, 134 F. $2 \mathrm{~d} 578$ (Ist Cir. 1943); and see Forster, supra note 12 , at 24.

${ }^{202}$ I PAUr, op. cit. stipra note $33, \$ 19.34$ (1946 Supp.).

${ }^{202} 4 \mathrm{Y}$ B. T. A. 294 (1940). The case is discussed in Forster, szipra note 12 , at 13 et seq. The opinion hints (p. 299) that an excess of insurance proceeds over purchase price will be considered "insurance." To avoid this it has become customary to stipulate in the agrcement that the purchase price shall be the greater of the agreed valuation or the insurance proceeds. There is another danger in a Legallet-type situation. Where a corporation pays premiums and the estate or family is the beneficiary, the premiums may be held to be income to the shareholder on whose life they are paid. ParamountRichards Theaters v. Commissioner, 153 F. 2d 602 (5th Cir. 1946).
} 
ums by the partnership qua partnership. The real question of taxation raised is, how many and which of these four earmarks are enough to bring about a Legallet result? It is submitted that certainly payment of premiums by the business entity alone is enough to bring on this result, since thereby it is hard to avoid the conclusion that the decedent paid for his own insurance. On the other hand, it is hard to see why merely naming a partner's wife should bring down the rule in all its force; that has to do with eventual enjoyment, not cost. But no sensible lawyer could conscientiously allow a plan embodying any two or more of these features to pass into being. There are no cases directly on the point, so here again the wise policy will be to avoid all appearance of the Legallet arrangement, probably even to the point of avoiding naming a member of the family as beneficiary.

The consequences of the Legallet opinion will be serious to the survivor. A turnover of inventory then becomes ordinary income so far as insurance proceeds are not includible in the cost basis of the inventory. ${ }^{103}$ The problem is not so serious for a shareholder survivor in a similar situation, for when he sells his shares he will first realize a gain, and that gain will be a capital gain and not ordinary income; stock is a capital asset.

There remain a few problems to be discussed briefly. They do not deserve extended treatment because they are neither so intricate nor in such a state of uncertainty as those to which more space has been given. By and large the questions now to be taken up are well settled and generally adequately handled in practice by lawyers and underwriters.

One such problem is that of the uninsurable member of the business association. In order that his colleagues may buy out his interest at his death several plans and combinations are commonly used. One method is for the other members of the group to deposit annually into a fund. The amounts deposited are generally equal to the premiums which would have had to be paid had he been insurable. This sort of situation is another argument for use of a trustee, since a trustee can hold these funds as part of his duties. Obviously, the odds are that an uninsurable will predecease the others, but in any event, to make up the balance of the purchase price the best solution is to have the sums not covered by the sinking fund paid by a series of notes with staggered dates of maturity; often such notes are secured by liens on the property owned by the business.

This same technique is generally used in cases where insurance is possible but where at death the value of the interest purchased exceeds, or may exceed, the proceeds of the insurance. It isn't as satisfactory as insurance but it is better than doing without an agreement.

Of course the instrument incorporating the agreement should contain many other provisions too numerous for more than mention here. For instance, it hardly

${ }^{103}$ The purchase of a decedent partner's interest is regarded as the purchase of an interest in the separate assets used in the business. Williams v. McGowan, 152 F. 2d 570 (2d Cir. 1945); Nathan Blum, 5 T. C. 702 (1945). 
needs to be said that there should be provisions for the case of inter vivos dissolution of the business association, probably including terms on which in that case the associates may buy the insurance on their own lives. ${ }^{104}$ There ought to be a clear statement of whether or not profits earned after a death are to be considered in the price paid by the survivors for the interest. ${ }^{105}$ Normally it is good practice to see to it that each member's will contains careful references to the agreement, together with instructions to the executor to perform all the acts necessary to carry it out. Clearly a clause should provide for amendment of the agreement. If a trustee is to be used, his duties and rights should be spelled out. In the case of a partnership each survivor partner should agree in the instrument to hold the estate of a decedent harmless from all debts of the partnership. And the agreement should specifically state that it binds not only the parties thereto, but also their heirs, executor, administrators, and assigns. A most convenient checklist can be obtained by anyone interested by writing to the life insurance companies to get their suggested forms; these are a great help to draftsmen so long as it is recalled that the buy and sell agreement must be not a suit off the rack, but one tailor-made. ${ }^{106}$

To conclude, business purchase plans coupled with life insurance are an increasingly common phenomenon, and one which lawyers must learn to handle. Although necessarily many different problems are involved in drafting them, the most important and elusive are the problem of establishing a fair price for the sale, of designating the beneficiary, of allocating premium payments, of attempting to make the valuation agreement as between the associates prevail for federal estate taxation as well, and of seeing to it that the cost basis of a survivor's interest for income tax purposes includes the insurance proceeds. Business purchase buy and sell agreements serve a most useful end and, properly handled, should in the future function both in estate planning and in "Business Planning." 107

${ }^{104}$ Cutler, Income Tax Consequences Following the Death or Withdrawal of a Partner, 28 B. U. L. REv. 7 (I948), treats tax effects of the withdrawal problem in partnership fully. Except in Texas (Cheeves v. Anders, 87 Tex. 287, 28 S. W. 274 (1894)) there is here no problem of insurable interest. William R. Vance, HandBook of the LaW of Insurance 149 (2d ed. 1930).

${ }^{100}$ Keyes v. Hurlbert, 43 Cal. App. 2d 497, III P. 2d 447 (I94I).

${ }^{100}$ Lawyers in cities of any size will find that life insurance agencies there will have two excellent sources of up-to-date information on buy and sell agreements: The Diamond Life Bulletins, 420 East Fourth St., Cincinnati 2, Ohio, and the Insurance Research and Review Service, Inc., of r23 West North St., Indianapolis, Indiana. The treatise by White, cited in this article, though written primarily for the underwriter, gives the most complete survey of the field.

${ }^{107}$ Chester Rohrlich, Organizing Corporate and Other Business Enterprises (1949), devotes his last chapter to the coordination of business and estate planning, with emphasis on planning for eventual death at the time the business is organized. A very recent and valuable article treating of the subject primarily from the economist's point of view is Harriss, Estate Taxes and the Family Owned Business, 38 CALIF. L. REv. II7 (1950). 